\title{
An Analysis of Speech Functions Realizations on the Electronics and Furniture Billboard Texts
}

\author{
Muhammad Hasyimsyah Batubara \\ Department of English, Faculty of Education, State Institute of Islamic Studies Takengon, Indonesia \\ Jalan Yos Sudarso No. 10 Takengon, Aceh Tengah, Aceh 24519, Indonesia \\ Corresponding author: muhammad.hasyimsyahbatubara@gmail.com
}

\begin{abstract}
This research analyzes the dominant category and to explains the tendency to use the speech functions model in electronics and furniture billboard texts. The research method used descriptive qualitative. Data was collected by applying documentary techniques from 32 commercial electronics and furniture billboard texts (headline, subhead, slogan, and images) in Medan. The results of the research found the four speech functions were used, the statement model was $62.5 \%$, the question model was $3 \%$, the command model was $18.8 \%$, and the offered model was $15.6 \%$. The statement model is used as the dominant one, in line with the billboard text pattern, where it is assumed to only see the display of billboard text and images with a duration of 5-7 seconds while driving. The substance of this research contributes in the form of new policy recommendations for advertisers to pay attention to speech in advertising communication messages conveyed correctly, precisely, and firmly. Advertisers are directed to pay more attention to the concept of the speech function with an efficient, effective, and hypnotic approach to readers. Keywords: Advertising; Speech Functions Model; Electronics and Furniture Billboard Texts
\end{abstract}

\begin{abstract}
Abstrak
Penelitian ini untuk menganalisis kategori dominan dan menjelaskan kecenderungan penggunaan model fungsi ujaran pada teks reklame elektronik dan furniture. Metode penelitian menggunakan deskriptif kualitatif. Data dikumpulkan dengan menerapkan teknik dokumenter dari 32 teks papan iklan elektronik dan furniture di sekitaran kota Medan. Hasil penelitian menemukan menggambarkan empat fungsi ujaran digunakan, model pernyataan sebesar 62,5\%, model pertanyaan sebesar 3\%, model perintah sebesar 18,8\%, dan model penawaran sebesar 15,6\%. Model pernyataan digunakan sebagai yang dominan, sejalan dengan pola teks papan reklame, di mana pemirsa diasumsikan hanya melihat tampilan teks dan gambar reklame dengan durasi 5-7 detik ketika mengemudi. Substansi penelitian ini memberikan kontribusi berupa rekomendasi kebijakan baru kepada pelaku periklanan untuk memerhatikan tutur komunikasi dalam periklanan agar pesan komunikasi tersampaikan secara benar, tepat, dan tegas. Para pelaku periklanan diarahkan agar lebih memerhatikan konsep fungsi ujaran dengan pendekatan efisiensi, efektiftifitas, dan mampu menghipnotis pembaca.
\end{abstract} Kata kunci: Periklanan; Model Fungsi Ujaran; Teks Reklame Elektronik dan Furniture

\section{Introduction}

In the Information and Communication Technologies (ICT) dimension, the ease of obtaining information has touched nearly the community's habit, thus giving a significant impact on the influence and taste in life choices. Mainly it is viewed from the side of commerce strategy where language functions are used and packaged in various styles to attract, trap the mind, and invite people perceptions. Language has the potential to influence the way of thinking of people with useful communication concepts so that the purpose of the utterance conveyed by the communicant can reside deep in the listener's mind.
Good communication skills are an essential asset in today's society, especially in building opportunities to market products. It requires product manufacturers to establish good communication in selling and get positive acceptance from consumers, especially in advertising communication, which aims to market products with advertising packaging that can influence readers or consumers on a large scale (Shimp, 2003; Cheung \& Lee, 2012). Furthermore, many theories can be applied in communication models, such as the interpersonal meaning approach, to conduct marketing communication. 
The process of transfer or acceptance of one's utterance can be used with approach interpersonal function, and it was done by being aware of the speech functions, be it in shape statement, question, offer, and command. It will immediately guide the public as speakers or authors and viewers or listeners in capturing the message of utterance in communication. Subsequently, we are competent to realize it as imperative if we had familiarity with the speech function at the preceding. Therefore, investigator consideration is necessary to research interpersonal role principally through the speech function angle in outdoor media advertising as a container of promoting used by a corporation. It is the reason the high potential and effective one because it directly reaches the purchaser.

In fact, there are various fields of speech function that be created as the object of study. Some of the previous research on speech function that the writer reads is speech function and speech role in the advertisement on television by Dalimunte (2012). The next study on the style and speech function on willingness to buy Bina Nusantara university students in Garuda Indonesia inflight magazine advertisement (Cahyono, 2013) and Wahyudihardjo and Clara (2014) conducted the presupposition and function of speech in advertisements for women's products.

In addition, this study tries to research billboard texts. One of the familiar outdoor media used to announce something and a remarkable marketing strategy in promoting products. It evolves in terms of size, language, choice of words, and desired visual aids. Billboards have now changed dramatically to support the speed of information in introducing new products displayed on the streets of big cities. They have developed not solely in the dimensions but also in language and the picture display that is attractive to the bare eyes.

Based on these considerations and to see the use of language on billboards in marketing products' tactics to lure the public's attention, the researcher is interested in seeing the uses of speech function in electronic and furniture billboards texts. It can describe the categories that dominate in its use and explain the factors of the study area's speech function phenomena.

\section{Interpersonal Meaning}

People use language to interact, construct a relationship with each of them. The fundamental speech roles that they can take on are giving and demanding. At the same time, they choose the speech role either to give or to demand in exchange. They also select the use of commodities that they are exchanging, namely, information, goods, and services. The interpersonal function is to notice interaction among speakers and listeners. Interpersonal communication plays an important role in shaping self-concept and identity, especially in social identity, because every interaction goes through the communication process (Annabella, 2013; Situmorang, 2016; Suparno, Sosiawan, \& Tripambudi, 2012). It is part of grammar selection that gives the speaker resources to interact with the listener by constructing and maintaining ongoing exchange with him or her, such as questioner and answerer, and by giving or requesting attitudes, comments, and evaluations (Morley, 2000). Furthermore, the interpersonal function also refers to a format of activity the speakers or writes in perform something toward the listeners or readers through language. In this study, the researcher intends to see the communication model with the interpersonal meaning approach carried out by producers or advertisers in marketing their products.

\section{Speech Functions}

Speech function is an action or performance by language users shown in the form of a statement, question, offer, and command (Halliday, 1994:30; Gerot, 1994:22; Morley, 2000:9). For example, I write many letters in the office (statement), could you send now, please? (question), would you like to have coffee? (offer), open the book! (command). Further, a statement form is a process of supply information in a positive or negative pattern. According to Grolier (1992) statement is the action of distributing information in speech and writing. The statement's format is subject placed in front of a verb or before the auxiliary verb, and it is closed with a period (.) (Collins, 
1998:96; Leech and Svartvik, 2003; Carter and McCarthy, 2006; Downing and Locke, 2006; Cobuild, 2011 in Batubara and Nasution, 2020).

A question form constitutes the method of demanding information by the pattern of interrogative expression, which is where this question takes a reply from the listener (Grolier, 1992:327). The form of the question type can be like 1)Yes orno-question, itcananswerwitha(yes) or (no). 2) Wh-question is using an interrogative word to ask for information. The question words are who, what, when, where, why, how, which are usually closed with a question mark (?). In further, they cannot be answered only with yes or no but with meaningful information. 3) Tag questions, it is a grammatical structure form in which a declarative or an imperative fragment (the 'tag"), such as 'right, don't you, doesn't he, etcetera. (Leech and Svartvik, 2003; Carter and McCarthy, 2006; Downing and Locke, 2006; Cobuild, 2011 in Batubara and Nasution, 2020).

An offer is a procedure of giving goods and services to someone. According to Collins (1998), the offer began to attach one of the modals, then attach by a subject and terminated with a question mark (?).An offer form is assumed as an expression of willingness to give something or continue something for acceptance or rejection (Grolier, 1992:268; Leech and Svartvik, 2003; Carter and McCarthy, 2006; Downing and Locke, 2006; Cobuild, 2011 in Batubara and Nasution, 2020).

A command is a system of expecting goods and services in the designimperative, and probably the format is a positive or negative command. According to Collins (1998), in the command sentence, the subject is omitted and the primary form of verbs used, or it begins by the predicate, and it is generally closed with an exclamation mark (!) (Leech and Svartvik, 2003; Carter and McCarthy, 2006; Downing and Locke, 2006; Cobuild, 2011 in Batubara and Nasution, 2020).

\section{Billboard}

Outdoor adv, outdoor sign, and poster, also known as a billboard, are ordinarily visible on highways, busy streets, and freeways use as advertising communication. The billboard's main purpose is how the advertising message can persuade consumers to use it later (Adelaar et al., 2003; Abideen and Saleem, 2011). According to Filiquarian (2008), billboards are divided into conservative billboards, mechanical billboards, digital billboards, and mobile billboards. In the recent era, billboards have become a medium of communication in introducing products because costs are lower than TV advertisements. Billboards are an advertising medium that is useful in introducing products among other advertising media and is useful for advertising products to increase (Hussain and Nizamani, 2011; Franke and Taylor, 2017; Chopra, 2017; Dhesi, 2018; Herrera and Pasch, 2018).

\section{Text}

Text is an arrangement of words that builds meaning, can be limited to phrases, or in the form of sentences, even in paragraphs. Saragih (2008:5) reveals that text is realized in sound, word, phrase, clause, sentence, or paragraph, and it is a discussion section of a semantic unit. In this case, the text is most likely to be found in the realm of advertising communications or copywriting. It exists on a headline, subhead, slogan, and body copy of advertising communication(Gilson and Berkmen, 1980:406).

\section{Headline}

Fundamentally, the headline one of the crucial elements in an advertisement and marketing communication (Alstiel and Grow, 2007:149). The headline is used to steal the reader's attention to the ad, and sometimes the concept can be displayed in a picture message. If the concept involves a combination of text and photos, it is recommended that the two be adjusted with a balanced weight.

\section{Subheads}

A subhead or breaker is a headline short enough to grab attention by providing more important information on a smaller basis. However, a long line underneath can break up long body copy and capsulate the advertisement's essential points. The subhead is generally under 
the title, although sometimes they immediately follow the title to say what the communicant wants and means (Alstiel and Grow, 2007:163). The subtitles' main function is to reinforce, clarify headline ideas, break up large copy, and direct the reader into the body copy.

\section{Slogan}

Alstiel and Grow (2007:163) The slogan is generally under the name of the sponsor of the ad, sometimes it becomes an emotionally provocative tag line, and it is very meaningful to the creator. E.g., Apple used Think Different, and Samsung carries the phrase Do What You Can't promote their exclusive products. This slogan relates to specific ideas, people, and groups whose purpose is to direct things, people, or groups, which are packaged in either a statement, an offer, an order, or even in a question so that the desired goal sticks to the reader.

Based on this background, this research analyzes the dominant category and to explains the tendency to use the speech functions model in electronics and furniture billboard texts.

\section{Research Methods}

According to Bogdan and Biklen (1992:30); Sugiyono (2005) uttered that the qualitative method is identical to descriptive. This research is applied a qualitative descriptive method. It used descriptive analysis because it tries to determine, identify, and describe what categories of speech function and why it is used dominantly in the electronic and furniture billboard texts.

This research requires the researcher to do fieldwork by physically traveling around the city of Medan to collect the source of data in one month. The data source taken is the commercial billboard texts placed in Medan. Data collection is through documentary techniques covering the following steps 1) the billboards texts are identified and located explicitly at the busiest streets or middle up societies in Medan. 2) the data are recorded or capture in both texts and pictures of the commercial billboards. 3 ) the data transcribed by printing them out (Creswell, 2014). Meanwhile, the data gathered as the sample is only ten percent (32) from the total number of electronic and furniture billboard texts are 328. It is base on Arikunto (2006:131) uttered that the sample is a portion or representative of the population studied, which means that not all populations included in the study. Thus, the data collected will represent the accuracy of the report (Meleong, 2002:6).

In analyzing the data applied is a descriptive analysis to draw speech function in commercial billboard texts. According to Miles and Huberman (1984); Miles, Huberman, and Saldana (2014), the data analyzed through four actions, namely 1) data collection, 2) reduction of data, 3) display of data, and 4) conclusions. The data collection carries out to collect all billboard texts without seeing whether it is commercial or noncommercial. Subsequently, in data reduction, the researcher will reduce the data based on the scope of this research in which the data used is only about the electronic and furniture billboard text. Later on, in the data display, the classifying of billboard texts based on speech function is done to calculate each speech function in the electronic and furniture billboard text by percentages will clearly. In conclusion, what and why is the most dominant form used in the electronic and furniture billboard text will be collected. Afterward, it will combine with the theory or previous research as the final achievement of this study.

\section{Results of Research and Discussion Types of Speech Functions in Electronics}

Electronic commercial billboard texts analyzed in this research are 17 texts containing three speech functions: statement, question, and command. The statement speech function found in this electronic billboard is 10 (61\%). Subsequently, the question speech function found in this electronic billboard is on 1 (5. $6 \%)$. Next, the command speech function found in this electronic billboard text is $6(33.3 \%)$. It signifies that the highly dominant speech function in the electronic billboard texts is a statement. Table 1 explains the data analyzed in the electronic area. From the table, it is known that there are seventeen texts interpreted in this 
Table 1 Form of Speech Functions in Electronics

\begin{tabular}{llcc}
\hline No & $\begin{array}{c}\text { Form of } \\
\text { Speech }\end{array}$ & Total & Percentage \\
\hline 1. & Statement & 10 & $61 \%$ \\
2. & Question & 1 & $6 \%$ \\
3. & Offer & 0 & 0 \\
4. & Command & 6 & $33 \%$ \\
& Total & 17 & $100 \%$ \\
\hline Source: & Results of Processed Researchers $(2020)$
\end{tabular}

Source: Results of Processed Researchers (2020)

domain. It acts as the representative objects from the whole commercial billboard texts in an electronic area that is one hundred and seventy-eight texts. Further, the distribution of speech functions is summarized in table 1 .

After analyzing the data, the statement is the most dominant one used in the electronic domain because electronics have high speed in varying the product. Thus, the company thought about how to sell the product as fast as possible. One way to achieve that goal is by using statement speech function in its billboard texts such as: 1) More fun More Affordable (Samsung TV); and 2) Panasonic Ideas For Life (Panasonic).

Sentences 1 and 2 explain how the products differentiated from other competitor products. They are brave in claiming such sentences because they believe the product has high quality.

A statement is also used as the most dominant one in the electronic domain because promoting electronics is as same as promoting good as the product. Thus, the language used by companies must be able to empower the quality of a product. The empowerment can be emerged by using the statement speech function among the four. Yule (1996) uttered that a successful reference depends on how viewers identify the reference written by companies in billboard texts to obtain the meaning. It means that the main point of conceptions commercial billboard texts directly says the point supported by reference so that the viewers do not need a long time to identify the meaning. It is because billboard texts on the street are read while viewers are driving or stopping at the traffic light.
Table 2 Form of Speech Functions in Furniture

\begin{tabular}{llcc}
\hline No & $\begin{array}{c}\text { Form of } \\
\text { Speech }\end{array}$ & Total & Percentage \\
\hline 1. & Statement & 10 & $66.7 \%$ \\
2. & Question & 0 & 0 \\
3. & Offer & 5 & $33.3 \%$ \\
4. & Command & 0 & 0 \\
& Total & 15 & $100 \%$ \\
\hline
\end{tabular}

Source: Results of Processed Researchers (2020)

Therefore, the use of a statement is dominantly attempted to be used, or even it is used ungrammatically to shorten the words so that the viewers can catch the meaning in less than 5 seconds. An example is the billboard text taken from Shard, which writes, "Bigger is Better". Actually, it comes from the sentence "it is more comfortable and healthier," but it is realized as a less effective language for billboard texts. That is why it shortened becomes only two words that are "Comfortable and Healthier". Moreover, it uses a comparison degree. It is because comparing one product is one of the simple and practical approaches for making a great advertisement (Alstiel and Grow, 2007:79).

In fact, the command form realized as an effective way to be used in billboard texts because the verb directly begins it without using any subject such as: (3) Do many Things the new way (Samsung Tab); and (4) Do more with smart TV (Samsung), etc.

In short, sentences 3 and 4 directly touch the point or meaning of making the advertisement. However, the company is not used because the company knows that their product is not as cheap as daily of need. Therefore, it is meaningless if the speech function used in the electronic billboard text is a command form as what is found in daily needs. That is the reason why the command form can only reach the second position, not the first position used in electronic billboard texts. 
The command form is issued because, in advertisement language, a command is defined as a campaign so that the viewers would like to consume the product directly. It is as what is stated by Alstiel and Grow (2007:130), a campaign is a concatenation of advertisement of a product or service to communicate the advertiser's request or message to the purchaser. For example, SHARP writes, "See beyond Reality" implicitly the company would like to ask viewers to buy the product (TV) individually if the viewers want to see beyond the reality. Even, it is an impolite way to ask the viewers to buy something, but it still has been chosen to be used because the approach of this command speech function is individual. It means that by using a command, there will be more product sold by the personal approach directly touch the viewer's mind individually.

In the end, there is only one question found in this electronic domain, such as: (5) How smart is Your 3 D (LG).

Sentence 5 in question is the lowest percentage because it cannot strongly persuade people to buy it. There are two possibilities for the question given. When the answer of viewers is NOT, it means that the advertisement fails in promoting the product. That is why it does not choose to be used. Thus, it can conclude that it is an alternative way chosen by companies in marketing their product through billboard texts.

From the presentation of the findings of this study in the realm of outdoorelectronic advertising in Medan, it provides a view to potential product advertisers to understand the useful speech function communication model in attracting the attention of the consumer community who is increasingly intelligent in providing choices on communication concepts made by advertisers.

\section{Types of Speech Functions in Furniture}

There are fifteen advertisement texts used in this study as a proportion of data sources from the furniture domain. It represents the one hundred and fifty commercial billboard texts of furniture placed on the street in this city. The data analysis done on the fifteen documents shows that there are only two speech functions found in this domain.
There are ten sentences formed in a statement, while there are five sentences built-in offer speech function. In contrast, question and offer form not used in furniture billboard texts. Further, the distribution is summarized in the table 2 .

Comercial billboard texts in furniture have a new phenomenon different from the previous domain data. The total number of statements used in the furniture domain is ten, while the total number of offers used in the furniture domain is five. Therefore, this point's conclusion is that statement acts as the most dominant speech function in commercial billboard texts of the furniture domain.

The statement is used dominantly in furniture because the company from the furniture domain does realize that statement has a powerful effect in claiming the quality of a product. It is as what is stated by Baack (2007) that the furniture store faced a variety of competitors, so that they need to claim it through statement speech function. The example found is. I'm in love with my bed (Elite Spring Bed)

Sentence implies that when will we be in love with our bed? So that we would like to buy the Elite Springbed order to feel hot to be in love with the bed.

A statement form is used as the most dominant with $66.7 \%$ because the advertisement will be more effective if it has a short and straightforward advertisement (Sharudin and Ibrahim, 2012). The quick and simple ad will be able to be obtained by using a statement because the real function of the statement form is to give information effectively and efficiently. Another reason for using statement form as the most dominant in furniture commercial billboard texts, because of the application of conceptions approaches in which the language used must show the product related to establishing or reinforce brand identity or period of a promotion time (Alstiel and Grow, 2007:79). As it is known among the four speech functions, the statement is the only one used to reinforce something. That is the reason why a statement form is used dominantly.

The offer form is then placed in the second position because it acts as the strategy for the company of furniture domain to sell the 
unsold out of the product. Baack argued that offer could raise price, quality, offering deals, or any other tactic. The examples found as such: (7) Buy mattress get free foundation \& headboard (Therapedic Spring bed); and (8) Buy small size get bigger size (Ocean spring bed)

The final goal of using this offer in sentences 7 and 8 is just to fasten the product selling because the stock will be changed with the new one. That is why the offer is also found in the furniture domain frequently.

Offer speech function emerges in the second rank as the language used in furniture commercial billboard texts. Lane, King, and Russell (2005:66) uttered that it is because there is a highly competitive environment that is more critical than ever for companies so that the companies use the offer to show the quality products of furniture that affordably meet viewers' needs. Thus, the result is the viewers' willingness, but the product after the offer form is given.

In addition, another reason for choosing offers in furniture commercial billboard texts because it realized that the offer form would also be able to hypnotize the viewers. It even makes the viewer's more sensitive in considering the product they will buy so that they are more critical in making decisions. Shimp (2000:118) stated that "para peneliti menemukan bahwa harga promosi membuat konsumen lebih sensitive dalam harga.". Thus, when the commercial billboard texts are provided with an offer, the companies will invite viewers' curiosity in accounting for the sale, discount, and etcetera. The message in the billboard texts is memorized automatically. Those are the reasons why the offer form is also used in high frequency after a statement.

There is no question form in these furniture billboard texts. It is thought of as the ineffective speech function in hypnotizing the brand in the viewer's mind because there has been a question in their mind about which brand of furniture they shall buy to fulfill their need? (Lane, King, and Russell (2005:92). Thus, when the language in billboard texts also given in question form, there will be double questions in the viewer's mind that makes them forget one of them. That is why the question type is not useful to be used in the furniture domain.
Last, a command is not used in furniture billboard texts because the cost offered in furniture billboard texts is relatively high. Thus, when it uses the command form, it is believed that it will not be able to ask the viewers to buy the product.

The research findings above are expected to provide a complete understanding for the producers of a product to choose a communication model that is more effective in communicating with the general public as the owner of the sustainability authority of a product being marketed.

\section{Conclusion}

In marketing communications on billboards found in the city of Medan, the use of the concept of interpersonal meaning with a speech function can be found easily. In this research, after the data is analyzed, the invention from the 32 texts found that all speech functions existed, in statement $20(62,5 \%)$, question 1 $(3 \%)$, command $6(18,8 \%)$, and offer $5(15,6 \%)$. It shows that the statement form is supremely dominant in electronics and furniture billboard text. It is appropriate with the principle concept of commercial billboard text that can only see in five to seven seconds, so it requires the language to be efficient, effective, and have a hypnotic effect on the reader, ultimately obtaining positive consumer action advertised goods.

Thus, advertisers need to pay attention to these findings to support the concept of communication used in advertising media. Moreover, the general public who read this article is part of the input in understanding the appearance of advertising communication speech acts, which in the end, people can take meaning in smartly delivered advertisements.

\section{References}

A. L. Herrera \& K. E. Pasch. (2018). Targeting Hispanic adolescents with outdoor food \& beverage advertising around schools. Journal of Ethnicity \& Health, 23(6), 691-702. https:// doi.org/10.1080/13557858.2017.1290217 
Abideen, Z.-U., \& Latif, A. (2011). Do Brand Extensions Affect Consumer Attitude: An Empirical Experience-With Reference To Pakistani Consumers. Journal of Applied Business Research, 27(2), 19-36. https://doi.org/10.19030/jabr.v27i2.4137 Adelaar, T., Chang, S., Lancendorfer, K. M., Lee, B., \& Morimoto, M. (2003). Effects of Media Formats on Emotions and Impulse Buying Intent. Journal of Information Technology, 18(4), 247-266. https://doi. org/10.1080/0268396032000150799

Alstiel, T. and Grow, J. (2007). Advertising Strategy. Singapore: Seng Lee Press. Annabella, G. (2013). Pengaruh Persepsi Mengenai Performa BlackBerry dan Intensitas Penggunaan Fitur BlackBerry Messenger Terhadap Perilaku Komunikasi Interpersonal. Jurnal Ilmu Komunikasi, 11(3), 259-269. https://doi.org/10.31315/jik.v11i3.3806 Arikunto, S. (2006). Prosedure Penelitian Suatu Pendekatan Praktek. Jakarta: Rineka Cipta. Baack, C. (2007). Integrated Advertising, Promotion and marketing Promotion (3rd ed.). New Delhi: Pearson Education. Batubara, M. H, Nasution, D. S. (2020). The Dominant Speech Functions in Cigarette Billboard Texts. JELTL (Journal of English Language Teaching and Linguistics), 5(2), 177-189. http:// dx.doi.org/10.21462/jeltl.v5i2.407 Bogdan, R.C. and Biklen, K. S. (1992). Qualitative Research for Education: An Introduction to Theory and Methods. Boston: Allyn and Bacon. Cahyono, R. A. N. T. (2013). Style And Speech Function On Willingness To Buy Of Bina Nusantara University Student In Garuda Indonesia Inflight Magazine Advertisement (BINUS). Retrieved from http://eprints2.binus.ac.id/id/eprint/28997 Carter, R. and M. M.(2006). Cambridge Grammar Of English A Comprehensive Guide Spoken and Written English Grammar and Usage. Cambridge: Cambridge University Press.
Cheung, C. M. K., \& Lee, M. K. O. (2012). What drives consumers to spread electronic word of mouth in online consumer-opinion platforms. Decision Support Systems, 53(1), 218-225. https://doi.org/http:// dx.doi.org/10.1016/j.dss.2012.01.015 Chopra, G. (2017). A Study on the Relationship Between Customer Attention and Billboards Advertising with Special Reference to Consumer. IOSR Journal of Humanities and Social Science (LOSR-JHSS), 22(11), 63-69. https://doi.org/10.9790/0837-2211136369

Cobuild, C. (2011). English Grammar. Glasgow: Harper Collins Publishers. Collins, P. (1998). English Grammar. South Melbourne: Longman.

Creswell,J..(2014).Researchdesign: Qualitative, quantitative, and mixed method approaches (4th ed). London: Sage Publication.

Dalimunte, A. A. (2012). Speech Function and speech role in advertisement on television (IAIN Sumatea Utara). Retrieved from http://repository.uinsu.ac.id/id/eprint/3521

Dhesi, D. (2018). The Uptrend of Outdoor Advertising. Retrieved July 9, 2020, from Malaysia: Star Media Group Berhad website: https://www.thestar.com.my/ business/business-news/2018/06/02/ the-uptrend-of-outdoor-advertising/

Downing, Angela and Locke, P. (2006). English Grammar A University Course (Second Edi). USA and Canada: Routledge. Filiquarian. (2008). Advertising-for- Knowit-alls. USA: Filiquarian Publising LLC.

Gerot, L. and P. W. (1994). Making Sense of Functional Grammar an Introducing Workbook. Sidney: GerdStabler.

Gilson, C \& Berkmen, W. . (1980). Advertising: advertising: concepts and strategies. Toronto: New York Random House.

Grolier, A. (1992). New Webster's Dictionary. Connecticut: Grolier Inc.

Halliday, M. A. K. (1994). An Introduction to Functional Grammar. London: Edward Arnold. 
Hussain, J. \& R. K. N. (2011). Factors Affecting Consumer Attention in Billboards Advertising. South Asian Journal of Management Sciences, 5(2), 60-64. Retrieved from https://econpapers. repec.org/article/ajmjournl/v_3a5_3a y_3a2011_3ai_3a2_3ap_3a60-64.htm

Lane Rolan. W and King Wiitehill. K \& Russel Tomas, J. (2005). Advertising Procedure (16th ed.). New Delhi: Pearson Education. Leech, G. and J. S. (2003). A Communicative Grammar of English (3rd Editio). London: Routledge.

Meleong, L. J. (2002). Metodologi Penelitian Kualitatif (Revisi). Bandung: Remaja Rosdakarya. Miles, M.B, Huberman, A.M. \& Saldana, J. (2014). Qualitative Data Analysis (Expanded.). London: Sage Publication, Inc. Miles, Matthew. B \& Huberman, M. A. (1984). Qualitative Data Analysis. London: Sage Publication, Inc. Morley, G. D. (2000). An Introduction to Systemic Grammar. Hong Kong: Macmillan. Saragih, A. (2008). Discourse Analysis: A Systemic Functional Approach the Analysis of Discourse and Texts. Medan: Unpublish.

Saragih, A. (2010). Introducing Systemic Functional Grammar of English. Medan: Unpublished.
Sharudin, A. S. and I. I. (2012). Formalistic concept in typography and layout applications in the Billboard Advertisement. 155-158. Retrieved from http://psrcentre. org/images/extraimages/311212640.pdf

Shimp, T. A. (2003). Periklanan Promosi (5th ed). Jakarta: Erlangga. Shimp, Terence A. (2000). Periklanan dan Promosi. Jakarta: Erlangga.

Situmorang, D. (2016). Peran Komunikasi Interpersonal Orang Tua dan Anak dalam Pendampingan Menonton Film Animasi. Jurnal Ilmu Komunikasi, 14(1), 57-67. https://doi.org/10.31315/jik.v14i1.2120 Sugiyono. (2005). Metode Penelitian Administrasi. Bandung: Alfabeta. Suparno, B., Sosiawan, E., \& Tripambudi, S. (2014). Computer Mediated Communication Situs Jejaring Sosial dan Identitas Diri Remaja. Jurnal Ilmu Komunikasi, 10(1), 85102. https://doi.org/10.31315/jik.v10i1.88

Taylor, G. R. F. \& C. R. (2017). Public Perceptions of Billboards: A Meta-Analysis. Journal of Advertising, 46(3), 395-410. https:// doi.org/10.1080/00913367.2017.1334248

Wahyudihardjo, N. A. C. H. K. (2014). Presupposition and Speech Function In Women Product Advertisements (BINUS). Retrieved from http:// eprints.binus.ac.id/Id/Eprint/30384 Yule, G. (1996). Pragmatics. Oxford: Oxford University Press. 